\title{
Seismic Retrofit of Flat Plate Structures
}

\author{
Woo-Seung Shin ${ }^{1}$, Jinkoo Kim ${ }^{2, *}$ \\ ${ }^{1}$ C.S Structural Engineering Inc., Seongnam 462-807, Korea \\ ${ }^{2}$ Department of Civil and Architectural Engineering, Sungkyunkwan University, Suwon 440-746, Korea \\ *Corresponding Author: jkim12@skku.edu
}

Copyright (C) 2013 Horizon Research Publishing All rights reserved.

\begin{abstract}
In this study flat plate structures designed only for gravity load were retrofitted against earthquake load using various methods and their seismic performances were evaluated to verify the effect of the seismic retrofit. Both the element level retrofit scheme such as column jacketing and the system level scheme such as installing steel braces between columns were employed. The nonlinear static and dynamic analysis results showed that both strength and stiffness were enhanced as a result of the seismic retrofit. Among the retrofit schemes steel braces were most effective in increasing stiffness as well as strength, and the effectiveness depended on the size of additional steel columns connected to the braces. Also the effect of column jacketing was significantly increased when the critical section of column-slab connection was reinforced by steel plate.
\end{abstract}

Keywords Seismic Retrofit, Flat Plate Structures, Braces, Column Jacketing

\section{Introduction}

For buildings not adequately designed for seismic load, seismic retrofit is an effective method of reducing the risks against earthquakes. Generally, there are two ways to enhance the seismic capacity of existing structures: the structure level and the member level approaches. The structure-level retrofit involves global modifications to the structural system, which includes addition of structural walls, steel braces, or base isolators/energy dissipators, etc. In the member-level approach the strength or ductility of components is increased to satisfy their specific limit states through addition of jackets to structural members.

The addition of steel bracing in an RC frame can be effective for global strengthening and stiffening of existing buildings. In this Scheme the capacity of the foundations must be checked since additional loads are imposed on the existing foundation at the bracing locations. Goel and Masri[1] tested a two-story RC slab-column frame specimen retrofitted by steel braces, and showed that the strength, stiffness, and energy dissipation capability increased due to the retrofit. The member level retrofit approaches include the addition of concrete, steel, or fiber-reinforced polymer (FRP) jackets for use in confining $\mathrm{RC}$ columns and joints. The response of a column in a building structure is controlled by its combined axial load, flexure, and shear. Therefore, column jacketing may be used to increase column shear and flexural strength so that columns are not damaged. In flat slab structures, punching shear failures are likely to occur if the slab is not designed for the combined effects of lateral and gravity loads. Several approaches to retrofitting deficient slab-column connections have been proposed. Masri and Goel [2], Luo and Durrani [3-4], and Martinez et al.[5] have reported using steel or concrete drop panels added below the slab to increase the punching shear perimeter and therefore the shear strength. Martinez et. al also presented results of tests in which the slab was retrofitted using steel plates on both sides of the slab with through-bolts to act as shear reinforcement.

In this study flat plate structures were designed not considering seismic load, and various seismic retrofit schemes were applied to enhance their seismic capacity. The seismic performance of the model structures was evaluated by nonlinear static and dynamic analyses using the program code OpenSees [6]. Generally a flat plate is modeled by an equivalent beam with appropriate width determined based on experimental data. In this study the effective width proposed by Luo and Durraniwas used to model the flat plate structures. The effective beam model was proposed based on experimental results and the effective beam width is determined as a function of column and slab aspect ratios and the magnitude of gravity load considering the stiffness reduction due to crack formation. Also the shear failure model at the critical section of slab-column joints proposed by Heuste and Wight [7] was applied in the analytical modeling. For seismic retrofit of the model structures both the structure level scheme, such as addition of steel braces, and the member level schemes, such as adding steel plate on column-slab joints and jacketing columns, were applied.

\section{Design and Analytical Modeling of Example Structures}


The prototype structures for analysis model are the 3and the 6-story 3-bay flat plate structures shown in Fig.1 From the structures the frames A and B were taken out and were connected by rigid links to form 2-dimensional analysis models (Fig. 1(b)).

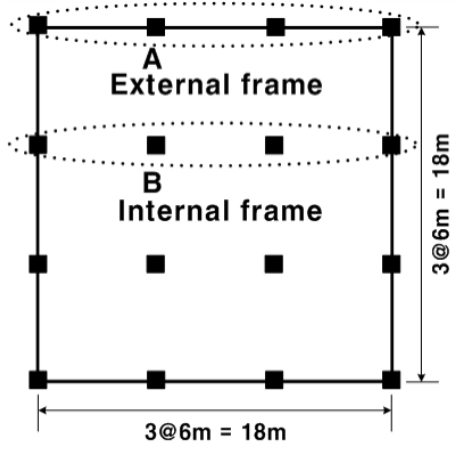

(a) Structural plan

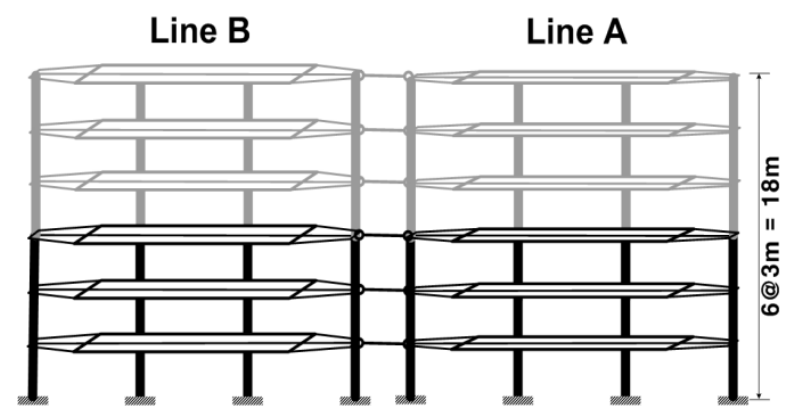

(b) Side view of the two-dimentional model

Figure 1. Flat plate analysis model structure

The structures were designed with dead load of 7.0 $\mathrm{kN} / \mathrm{m} 2$ and live load of $2.5 \mathrm{kN} / \mathrm{m} 2$, and the slabs were modeled as equivalent beams. Table1 shows the size of columns and reinforcing steel. The slabs were modeled as effective beams, and the width of the effective beams was determined using the model proposed by Ruo and Durrani [3-4] which includes the stiffness reduction factor presented in (1):

$$
x=1-0.4 \frac{V_{g}}{4 A_{c} \sqrt{f_{c}^{\prime}}}
$$

where $V_{g}$ is the shear force caused by gravity loads, $A_{c}$ is the area of slab critical section, and $f_{c}^{\prime}$ is the compressive strength of concrete. Using the stiffness reduction factor, the widths of internal and external effective beams were computed as $l^{\prime}=x \alpha_{i} l$ for internal frames and $l^{\prime}=x \alpha_{e} l$ for external frames, where $l$ is the span length, and $\alpha_{i}$ and $\alpha_{e}$ are the effective width factors for slab at interior and exterior connections, respectively, obtained as follows:

$$
\begin{gathered}
\alpha_{i}=\frac{R_{12}\left(\frac{c_{2}}{c_{1}}\right)}{0.05+0.002\left(\frac{l_{1}}{l_{2}}\right)^{4}-2\left(\frac{(1}{l_{1}}\right)^{3}-2.8\left(\frac{c_{1}}{l_{1}}\right)^{2}+1.1\left(\frac{c_{1}}{l_{1}}\right)^{2}} ; \alpha_{e}=\frac{K_{t}}{K_{t}+K_{S}} \\
R_{12}=\left\{-2.21\left(\frac{c_{1}}{c_{2}}\right)^{4}+2.81\left(\frac{c_{1}}{c_{2}}\right)^{3}+15.35\left(\frac{c_{1}}{c_{2}}\right)^{2}+7.73\left(\frac{c_{1}}{c_{2}}\right)+8.45\right\} 10^{-2}
\end{gathered}
$$

where

$\mathrm{K}_{\mathrm{t}}$ and $\mathrm{K}_{\mathrm{s}}$ are the torsional and flexural stiffness of members, respectively; $1_{1}$ and $l_{2}$ are the span lengths in the longitudinal and transverse directions, respectively; $\mathrm{c}_{1}$ and $\mathrm{c}_{2}$ are the column dimensions in bending direction and in the normal to bending direction, respectively.

Table 1. Sizes and reinforcements of columns in model structures

(a) 3-story structure

\begin{tabular}{|c|c|}
\hline Cross-sectional size $(\mathrm{mm})$ & Reinforcement $(\mathrm{mm})$ \\
\hline \hline $400 \times 400$ & $8-\mathrm{D} 22(\mathrm{D} 10 @ 300)$ \\
\hline $300 \times 300$ & 4-D22 (D10@300) \\
\hline
\end{tabular}

(b) 6-story structure

\begin{tabular}{|c|c|c|}
\hline Cross-sectionalsize $(\mathrm{mm})$ & Story & Reinforcement $(\mathrm{mm})$ \\
\hline \hline \multirow{2}{*}{$500 \times 500$} & $1-3$ & 12-D22 (D10@300) \\
\cline { 2 - 3 } & $4-6$ & 4-D29 (D10@300) \\
\hline \multirow{2}{*}{$400 \times 400$} & $1-3$ & 8-D22 (D10@300) \\
\cline { 2 - 3 } & $4-6$ & 4-D25 (D10@300) \\
\hline \multirow{2}{*}{$300 \times 300$} & $1-3$ & 4-D22 (D10@300) \\
\cline { 2 - 3 } & $4-6$ & 4-D19 (D10@300) \\
\hline
\end{tabular}

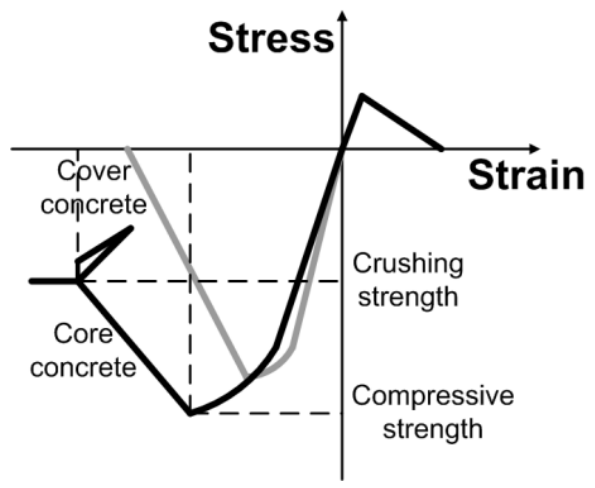

(a)Concrete

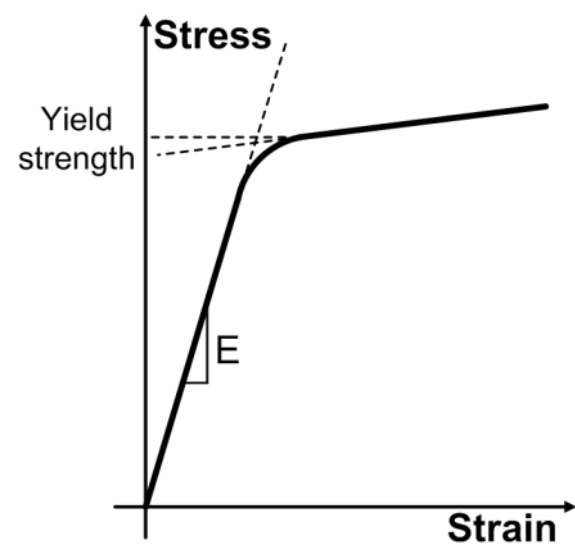

(b)Steel

Figure 2. Stress-strain relationship of materials 
Table 2. Effective beam width, reinforcement, and punching shear failure angle of flat plates

(a) 3-story structure

\begin{tabular}{|c|c|c|c|c|c|c|c|}
\hline \multirow{2}{*}{ Line } & \multirow{2}{*}{ Bay } & \multirow{2}{*}{$\begin{array}{c}\text { Effective } \\
\text { width } \\
(\mathrm{mm})\end{array}$} & \multirow{2}{*}{ Moment } & \multicolumn{2}{|c|}{ Reinforcing steel } & \multicolumn{2}{|c|}{$\begin{array}{l}\text { Punching shear } \\
\text { failure }\end{array}$} \\
\hline & & & & Top & Bottom & $\mathrm{Vg} / \mathrm{Vc}$ & $\begin{array}{c}\text { Failure } \\
\text { angle(rad) }\end{array}$ \\
\hline \multirow{5}{*}{ B } & \multirow{2}{*}{ Int. } & \multirow{2}{*}{3500} & Negative & 33-D13 & 12-D13 & \multirow{2}{*}{0.47} & 0.00402 \\
\hline & & & Positive & 12-D13 & 11-D13 & & 0.00733 \\
\hline & \multirow{3}{*}{ Ext. } & 3300 & $\mathrm{~N}$ & 36-D13 & 22-D13 & \multirow{3}{*}{0.43} & \multirow{3}{*}{ - } \\
\hline & & 2900 & $\mathrm{P}$ & 11-D13 & 14-D13 & & \\
\hline & & 2400 & $\mathrm{~N}$ & 8-D13 & 8-D13 & & \\
\hline \multirow{5}{*}{ A } & \multirow{2}{*}{ Int. } & \multirow{2}{*}{1600} & $\mathrm{~N}$ & 9-D13 & 5-D13 & \multirow{2}{*}{0.43} & 0.00419 \\
\hline & & & $\mathrm{P}$ & 5-D13 & 5-D13 & & 0.00757 \\
\hline & \multirow{3}{*}{ Ext. } & 1600 & $\mathrm{~N}$ & 9-D13 & 6-D13 & \multirow{3}{*}{0.35} & \multirow{3}{*}{ - } \\
\hline & & 1400 & $\mathrm{P}$ & 5-D13 & 5-D13 & & \\
\hline & & 1300 & $\mathrm{~N}$ & 4-D13 & 4-D13 & & \\
\hline
\end{tabular}

(b) 6-story structure

\begin{tabular}{|c|c|c|c|c|c|c|c|}
\hline \multirow[b]{2}{*}{ Line } & \multirow[b]{2}{*}{ Bay } & \multirow{2}{*}{$\begin{array}{l}\text { Effective } \\
\text { width } \\
(\mathrm{mm})\end{array}$} & \multirow{2}{*}{ Moment } & \multicolumn{2}{|c|}{ Reinforcing steel } & \multicolumn{2}{|c|}{$\begin{array}{l}\text { Punching shear } \\
\text { failure }\end{array}$} \\
\hline & & & & Top & Bottom & $\mathrm{Vg} / \mathrm{Vc}$ & $\begin{array}{c}\text { Failure } \\
\text { angle(rad) }\end{array}$ \\
\hline \multirow{5}{*}{ B } & \multirow{2}{*}{ Int. } & \multirow{2}{*}{4000} & $\mathrm{~N}$ & 31-D13 & 14-D13 & \multirow{2}{*}{0.40} & 0.01048 \\
\hline & & & $\mathrm{P}$ & $13-\mathrm{D} 13$ & $13-\mathrm{D} 13$ & & 0.02966 \\
\hline & \multirow{3}{*}{ Ext. } & 3900 & $\mathrm{~N}$ & $35-\mathrm{D} 13$ & 23-D13 & \multirow{3}{*}{0.27} & \multirow{3}{*}{ - } \\
\hline & & 3500 & $\mathrm{P}$ & 12-D13 & $15-\mathrm{D} 13$ & & \\
\hline & & 3000 & $\mathrm{~N}$ & 12-D13 & 10-D13 & & \\
\hline \multirow{5}{*}{ A } & \multirow{2}{*}{ Int. } & \multirow{2}{*}{1800} & $\mathrm{~N}$ & 9-D13 & 6-D13 & \multirow{2}{*}{0.27} & 0.03156 \\
\hline & & & $\mathrm{P}$ & 6-D13 & $6-\mathrm{D} 13$ & & 0.08928 \\
\hline & \multirow{3}{*}{ Ext. } & 1700 & $\mathrm{~N}$ & 10-D13 & 6-D13 & \multirow{3}{*}{0.23} & \multirow{3}{*}{ - } \\
\hline & & 1500 & $\mathrm{P}$ & 5-D13 & $5-\mathrm{D} 13$ & & \\
\hline & & 1300 & $\mathrm{~N}$ & 4-D13 & 4-D13 & & \\
\hline
\end{tabular}

Table 2 shows the effective beam widths of model structures determined based on the amount of reinforcing steel and the above model. The nominal strengths of concrete and reinforcing steel used for designing the model structures are $21 \mathrm{MPa}$ and $300 \mathrm{MPa}$, respectively, and the expected ultimate strengths of the materials used for performance evaluation are 28.67 $\mathrm{MPa}$ and $375 \mathrm{MPa}$, respectively. The post-yield stiffness of the reinforcing steel is assumed to be $2 \%$ of the initial stiffness. The stress-strain relationship of concrete, shown in Fig. 2(a), was determined based on the equation proposed by Mander et al.[8] which considers the confining effect of reinforcing steel. The stress-strain relationship of reinforcing steel was assumed to be bi-linear as shown in Fig. 2(b). Vandebilt and
Corley[9]proposed the stiffness reduction factor of $1 / 3$ to $1 / 4$ for effective beams. ACI 318-05 [10] recommends to reduce the stiffness $1 / 2$ to $1 / 4$ for effective beams. Based on experiments Choi and Song [11] suggested to use $1 / 3$ as a stiffness reduction factor for internal frames and $1 / 4$ for external frames. Park et al. [12] found that the reduction factor specified in the ACI 318-05 underestimated the experimental results and proposed an equation for stiffness reduction factor as a function of the ratio of applied bending moment and crack moment. Fig.3 compares the second-story effective beam bending moment $v s$. the inter-story drift ratio of the 3-story model structure obtained by pushover analysis using the nonlinear fiber section provided in the OpenSees and the beam elements considering the stiffness reduction factors proposed previously. It can be observed that the results obtained using the nonlinear fiber section matches well with those obtained by beam elements considering the stiffness reduction factor. In this study the nonlinear fiber section was used to model most structural members except the slab-column joints in which nonlinear pinching model was used.

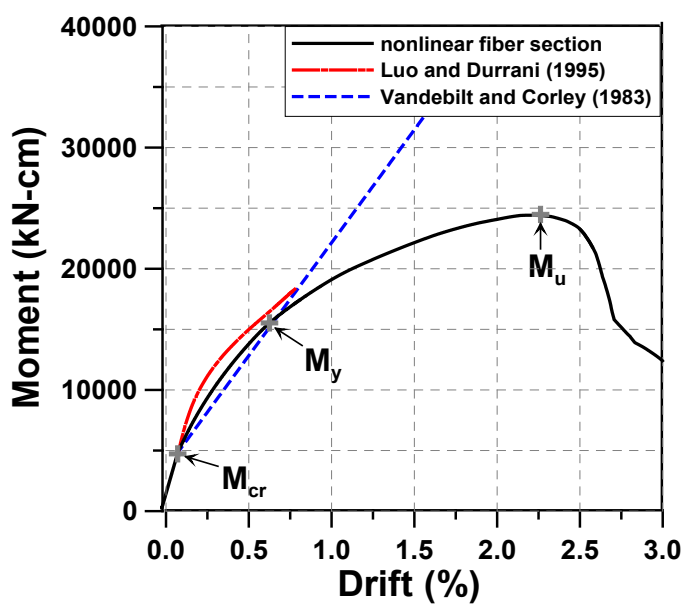

(a) Exterior frame

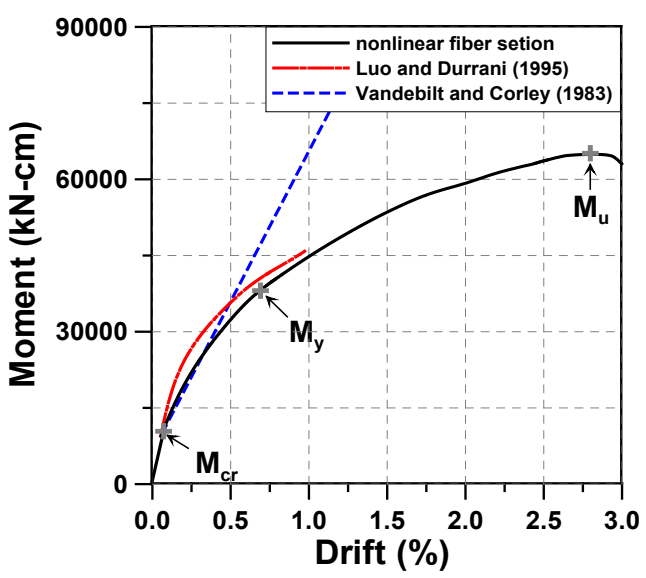

(b) Interior frame

Figure 3. Bending moment-drift curves of the second story effective beam 


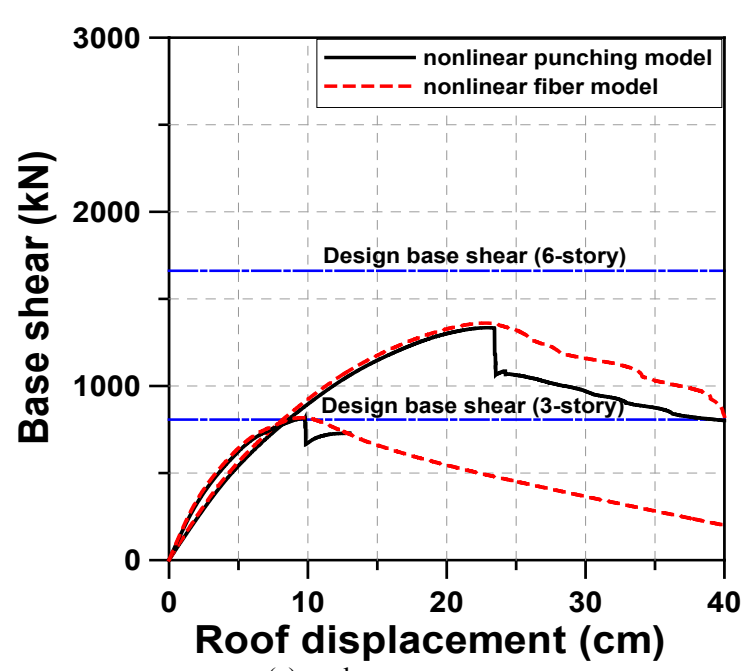

(a) pushover curves

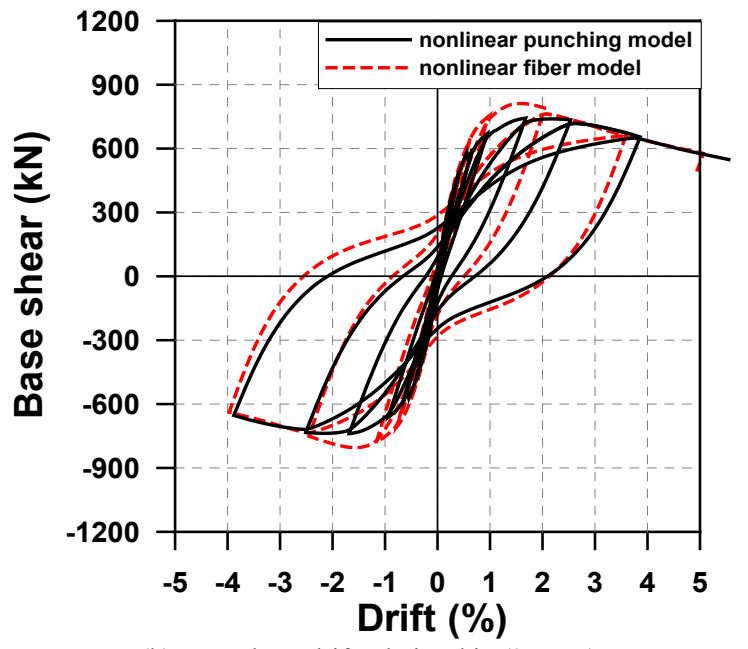

(b) Base shear-drift relationship (3-story)

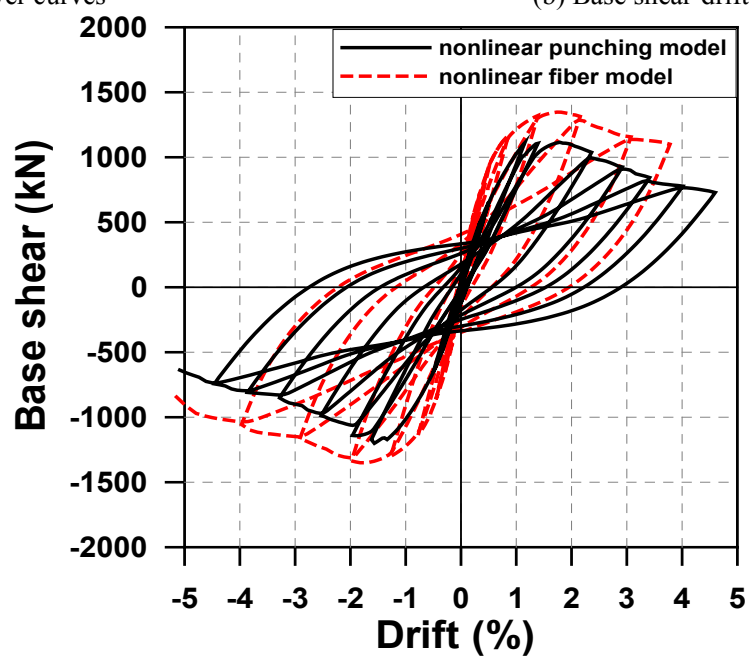

(c) Base shear-drift relationship (6-story)

Figure 7. Comparison of structural behavior predicted by nonlinear fiber element and nonlinear pinching element at column-slab connections

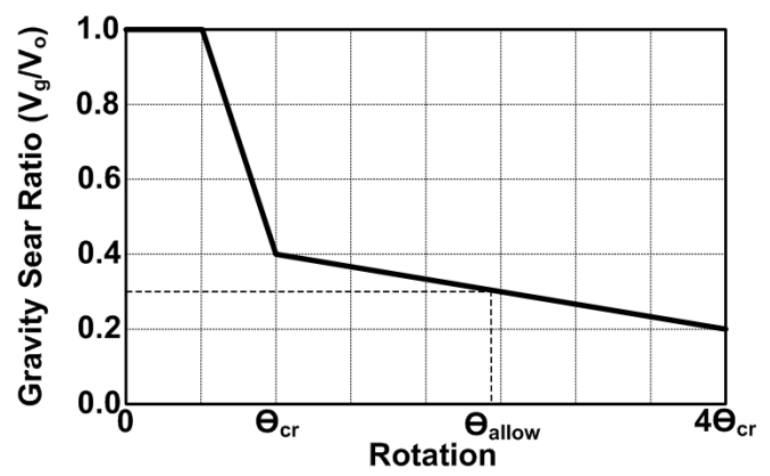

Figure 4. Punching shear failure model using gravity shear force ratio-member end rotation at critical section (Heuste and Wight, 1999)

Fig.4 depicts the punching shear failure model for slab-column connections proposed by Heuste and Wight [6] based on experimental results. The failure model specifies relationship between the gravity shear ratio, $V_{g} / V_{c}$, and the allowable rotation of effective beam, $\theta_{\text {allow }}$, as shown in the figure. In this study $\theta_{c r}$ was obtained by averaging the column-slab rotation angles of all stories when the maximum drift $\left(\Delta_{\text {roof }} / H\right)$ reached $1.5 \%$ of the story height in pushover analysis. Elwood and Moehle [13] used hysteretic material with shear and axial spring to model the punching shear and obtained analysis results which correspond well with experimental results. In this study the column-slab connection is modeled by nonlinear pinching element which can account for the punching shear failure. The bending moment-joint rotation relationship of the column-slab connection modeled by nonlinear pinching material provided in the OpenSees is shown in Fig. 5. The allowable rotation $\theta_{\text {allow }}$ can be obtained from the line between $\theta_{c r}$ and $4 \theta_{c r}$ in Fig. 4 corresponding to the given value of $V_{g} / V_{c}$.

In Fig. 6 the cyclic behavior of a column-slab connection simulated by nonlinear pinching elements considering punching shear failure is compared with the connection behavior predicted using nonlinear fiber elements which do not consider strength degradation by punching shear. It can be observed that the use of nonlinear pinching model results in highly brittle connection behavior caused by punching shear failure. Fig. 7 compares the pushover curves and the 
base shear $v s$. maximum displacement relationship of the model structures simulated by using nonlinear fiber and nonlinear pinching elements at column-slab connections. It can be observed that the use of pinching elements better represents the abrupt strength drop due to punching shear, and that the strength degradation by punching shear is more predominant in the 6-story structure. In this study the nonlinear pinching elements were used to model the slab-column connections while the nonlinear fiber elements were used for the rest of the structure.

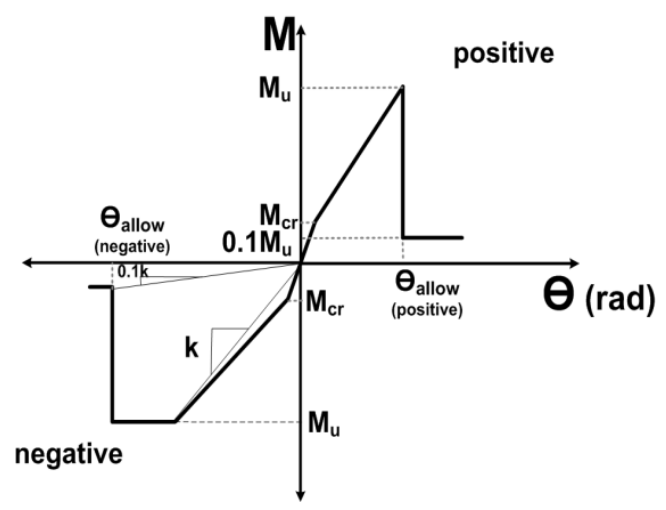

Figure 5. Behavior of nonlinear pinching element for column-slab connection

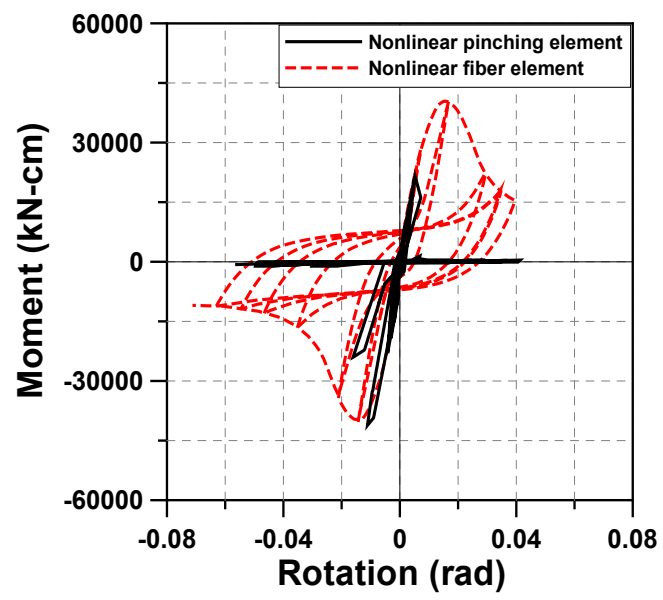

Figure 6. Cyclic behavior of a column-slab connection modeled by nonlinear fiber element and nonlinear pinching element

\section{Applied Seismic Retrofit Schemes}

The model structures not designed for seismic load were retrofitted to meet the current seismic design load of KBC 2009 by various schemes. The design seismic load was computed based on the seismic coefficients $\mathrm{S}_{\mathrm{DS}}=0.53 \mathrm{~g}$ and $\mathrm{S}_{\mathrm{D} 1}=0.34$ gin the IBC [14]format. The steel plates and braces used for retrofit were made of SM $400\left(F_{y}=23.5\right.$ $\mathrm{MPa}$ )and the columns used with braces were made of SM $490\left(F_{y}=32.4 \mathrm{MPa}\right)$ steel.

\subsection{Column Jacketing}

The columns were jacketed by steel plates to increase strength and ductility of the model structures. The thickness of steel plates used for column jacketing is presented in Table 3. The jacketed columns were modeled by nonlinear fiber section having the stress-strain relationship proposed by Susantha et al.[15] for concrete-filled steel tube columns.

Table 3. Thickness of steel plates used for column jacketing (mm)(w/o: without effective beam reinforcement; with: with reinforcement)

(a) 3-story structure

\begin{tabular}{|c|c|c|c|c|c|c|}
\hline \multirow{2}{*}{} & \multicolumn{2}{|c|}{ 1st story } & \multicolumn{2}{c|}{ 2nd story } & \multicolumn{2}{c|}{ 3rd story } \\
\cline { 2 - 7 } & w/o & with & w/o & with & w/o & with \\
\hline \hline Inner columns & 13 & 12 & 5 & 6 & 5 & 5 \\
\hline Ext. columns & 8 & 7 & 6 & 6 & 6 & 6 \\
\hline Corner columns & 5 & 5 & 3 & 3 & 3 & 3 \\
\hline
\end{tabular}

(b) 6-story structure

\begin{tabular}{|c|c|c|c|c|c|c|}
\hline \multirow{2}{*}{} & \multicolumn{2}{|c|}{ 1st-2nd } & \multicolumn{2}{c|}{ 3rd-4th } & \multicolumn{2}{c|}{ 5th-6th } \\
\cline { 2 - 7 } & w/o & with & w/o & with & w/o & with \\
\hline \hline Inner columns & 30 & 25 & 5 & 6 & 5 & 5 \\
\hline Ext. columns & 20 & 17 & 6 & 6 & 6 & 6 \\
\hline Corner columns & 5 & 5 & 3 & 3 & 3 & 3 \\
\hline
\end{tabular}

Table 4. Size of reinforcing braces $(\mathrm{mm})$

\begin{tabular}{|c|c|c|}
\hline Model structures & Story & H-shaped sections $(\mathrm{mm})$ \\
\hline \hline \multirow{3}{*}{3 -story } & 1 & $208 \times 202 \times 10 \times 16$ \\
\cline { 2 - 3 } & 2 & $200 \times 200 \times 8 \times 12$ \\
\cline { 2 - 3 } & 3 & $175 \times 175 \times 7.5 \times 11$ \\
\hline \multirow{3}{*}{ 6-story } & $1 \sim 2$ & $300 \times 300 \times 10 \times 15$ \\
\cline { 2 - 3 } & $3 \sim 4$ & $294 \times 302 \times 12 \times 12$ \\
\cline { 2 - 3 } & $5 \sim 6$ & $208 \times 202 \times 10 \times 16$ \\
\hline
\end{tabular}

Table 5. Size of added steel columns (mm)

\begin{tabular}{|c|c|c|}
\hline Model structures & Story & H-shaped sections (mm) \\
\hline \hline \multirow{2}{*}{ 3-story } & $1 \sim 3$ & $208 \times 202 \times 10 \times 16$ \\
\hline \multirow{2}{*}{ 6-story } & $1 \sim 2$ & $300 \times 300 \times 10 \times 15$ \\
\cline { 2 - 3 } & $3 \sim 4$ & $294 \times 302 \times 12 \times 12$ \\
\cline { 2 - 3 } & $5 \sim 6$ & $208 \times 202 \times 10 \times 16$ \\
\hline
\end{tabular}

\subsection{Steel Bracing}

Diagonal steel braces were installed as shown in Fig. 8. As large axial force was induced to the existing columns attached to the added braces, additional steel columns were attached to the existing concrete columns and the braces were connected to the steel columns. Tables 4 and 5 show the sizes of braces and steel columns, respectively, added for seismic retrofit. 


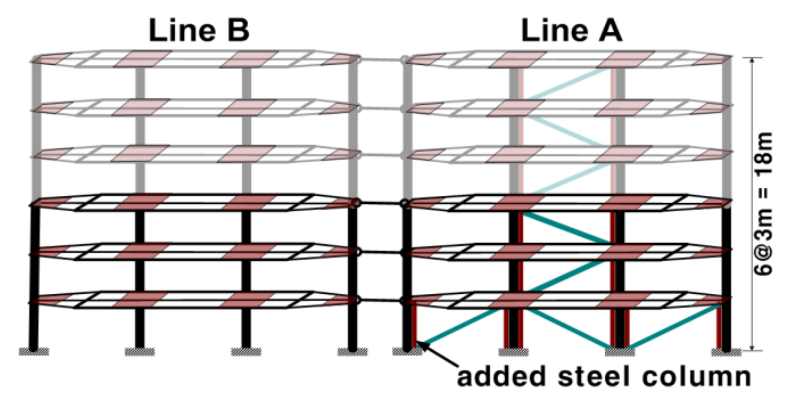

Figure 8. Retrofit of model structures by diagonal braces

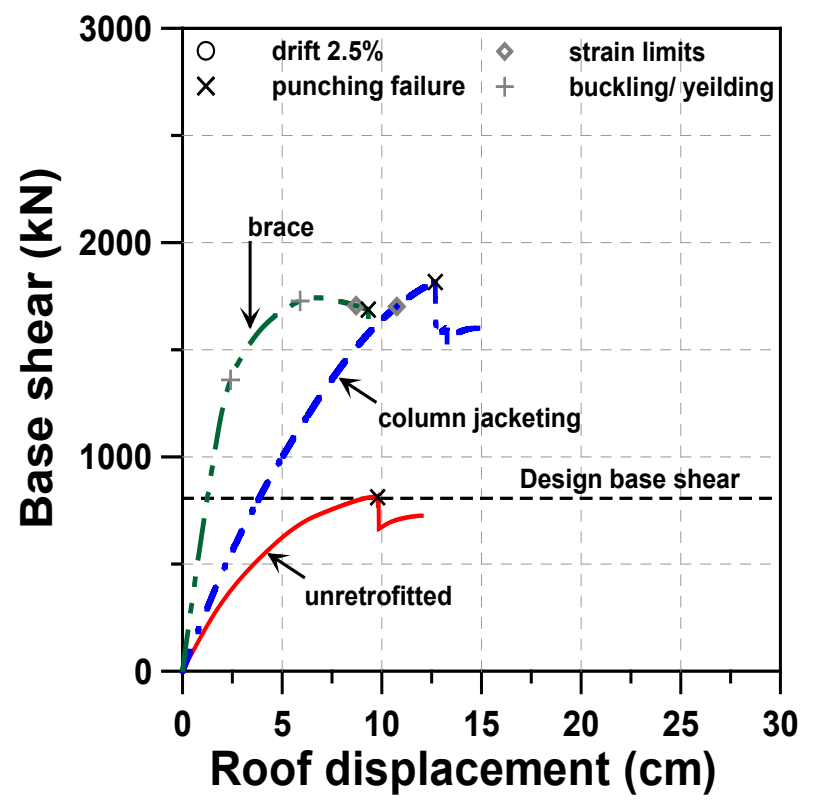

(a) 3-story

\subsection{Reinforcement of Column-Slab Connection}

In slab-column connections, punching shear failure due to unbalanced moments is the most critical type of structural damage. In this study, along with the column jacketing and installation of braces, the effective beams were reinforced by steel plates to increase resistance to punching shear failure. After the reinforcement, the gravity shear ratios for the 3-story and 6-story model structures were decreased to 0.26 and 0.22 , respectively. The thickness of the steel plates was determined based on the negative and positive moments of the effective beams.

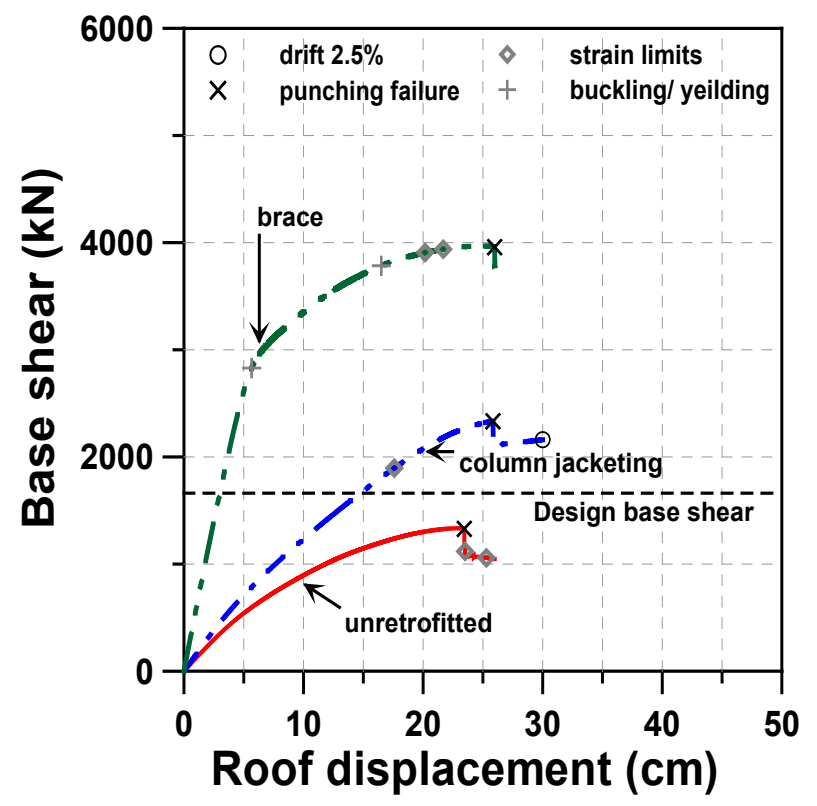

(b) 6-story

Figure 9. Pushover curves of the model structures retrofitted without slabreinforcement

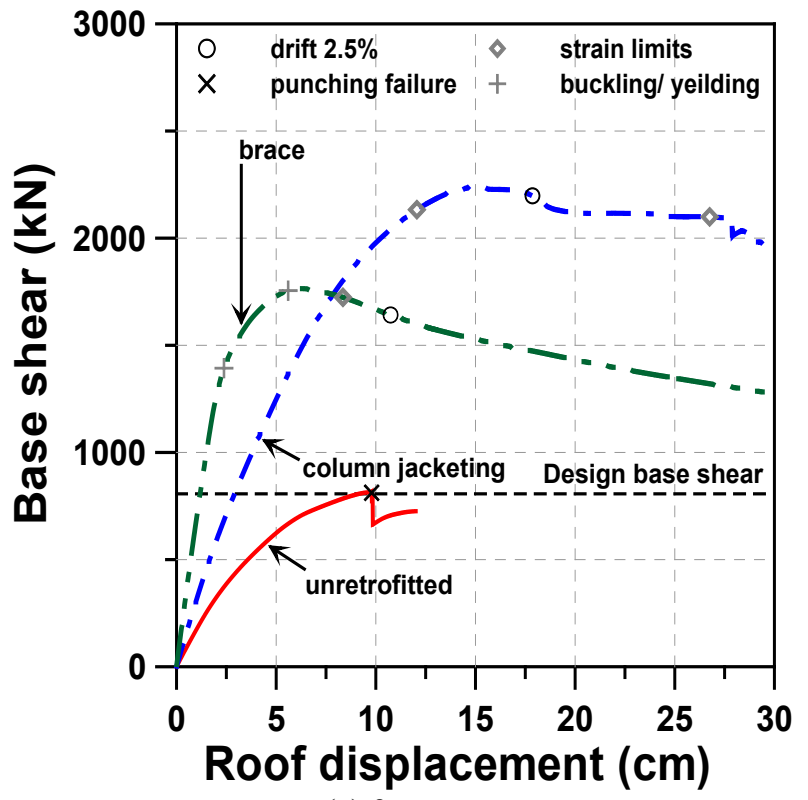

(a) 3-story

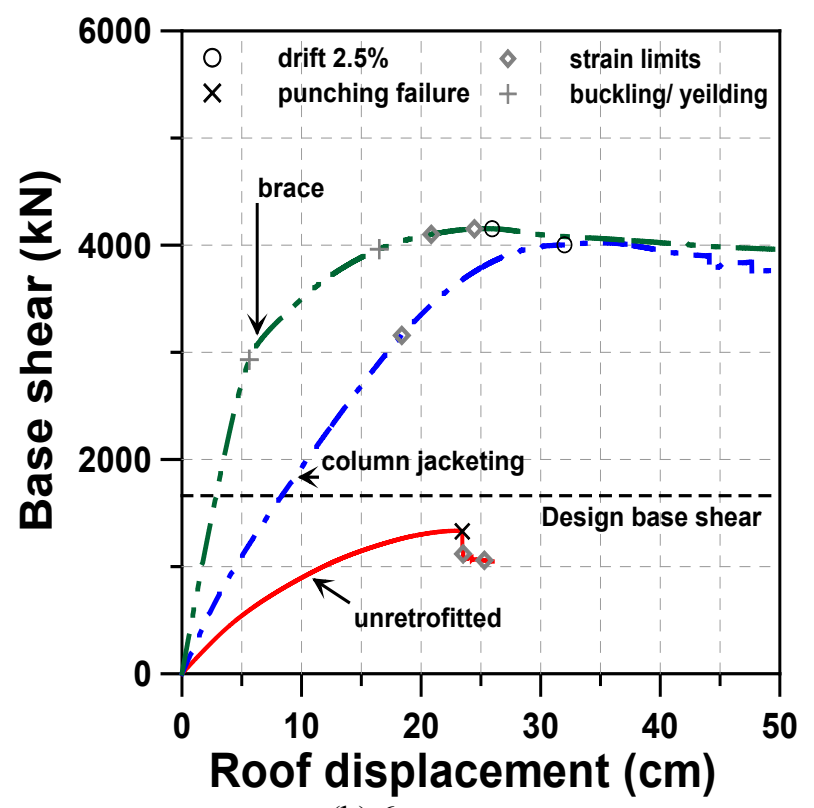

(b) 6-story

Figure 10. Pushover curves of the model structures with slab reinforcement 


\section{Seismic Performance Evaluation of Model Structures}

\subsection{Nonlinear Static Analysis Results}

It is important to perform accurate seismic evaluation of an existing structure to select an appropriate retrofitting strategy and to confirm its effectiveness. In this study pushover analyses were carried out by increasing the lateral displacement gradually. The seismic story forces were distributed vertically proportional to the first mode of vibration for pushover analysis. It was assumed that the effective beams started to fail when the compressive strain of concrete reached 0.003 . The failure of columns was determined based on the equation for ultimate strain proposed by Mander et al. considering the confining effect of tie bars.

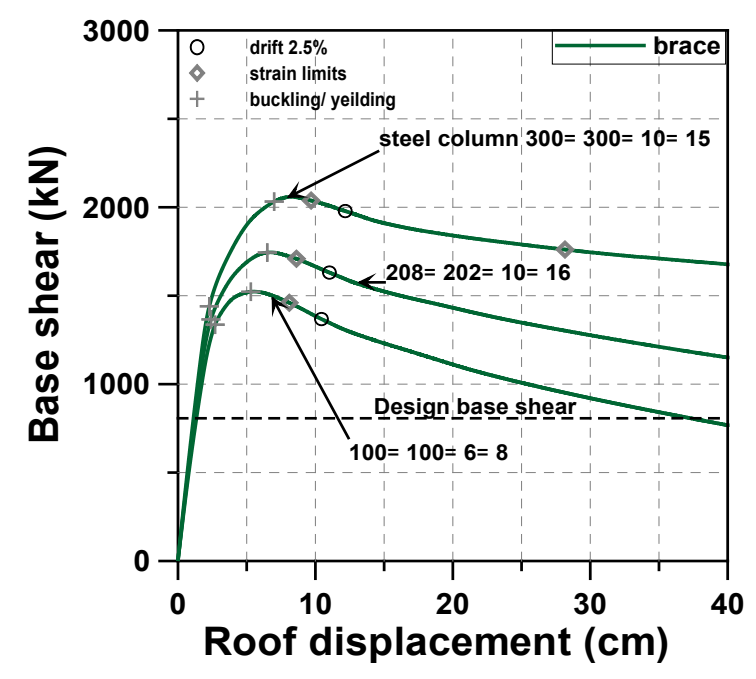

(a) 3-story

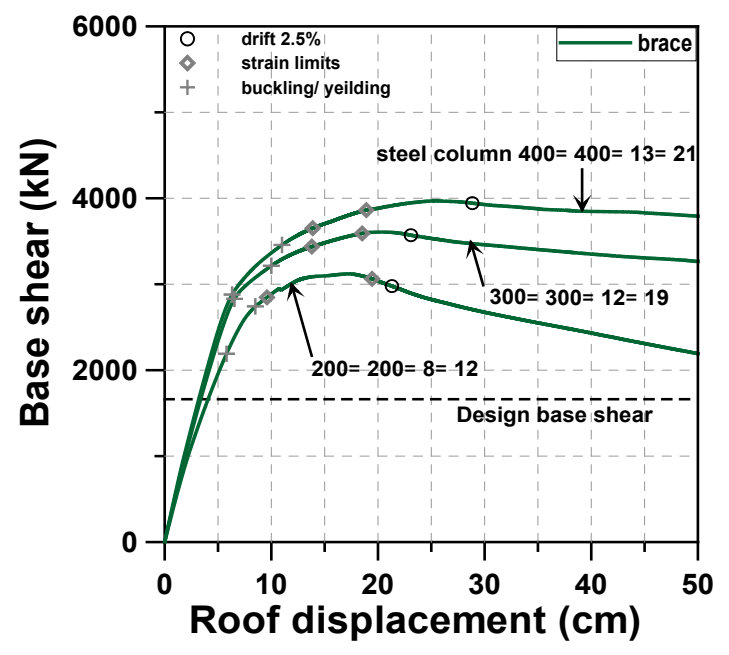

(b) 6-story

Figure 11. Pushover curves of model structures retrofitted by steel braces

Figs. 9 and 10 depict the pushover curves of the model structures without and with slab reinforcement, respectively. It can be observed that the strength of the unreinforced structures do not meet the design base shear and they failed by premature punching shear failure. In the 3-story structure with gravity shear ratio of $V_{g} / V_{c}=0.47$ punching shear failure occurred in slab before flexural strain limit was exceeded in extreme fiber of columns and/or effective beams. In the 6-story structure with $V_{g} / V_{c}=0.4$ the punching shear failure occurred after the local failure of columns and/or beams. It was observed that the stiffness of model structures increased by 150 to $412 \%$ in the 3 -story structure and by 145 to $456 \%$ in the 6-story structure after the structures was retrofitted for design seismic load. The ultimate strength also increased by 215 to $276 \%$ in the 3 -story structure and by 173 to $313 \%$ in the 6-story structure. The maximum drift ratio, $\Delta_{\text {roof }} / H$, at punching shear failure increased to 0.013 (3-story) and 0.014 (6-story) after the retrofit. By comparing Figs. 9 and 10 it can be observed that the strength of the structures retrofitted with steel braces is not affected significantly by the steel plate reinforcement of column-slab connections. This is due to the fact that in the flat plate structure with steel braces the effective beams do not contribute much to resisting lateral load. However the strength of the structures with jacketed columns increased significantly with the steel plate reinforcement of slab-column connections because the effective beams as well as columns resist the lateral load as moment frames.

Fig. 11 plots the pushover curves of the model structures retrofitted with steel braces with various sizes of added steel columns. It can be observed that, as the maximum strength of the model structures is reached right before the buckling of an added steel column, the overall strength increases as the column size increases.

Fig. 12 compares the pushover curves of the 3-story structure retrofitted with conventional steel braces and with buckling-restrained braces (BRBs). As the buckling-restrained braces yield under both tension and compression, members with smaller cross sections are selected for given design load compared with conventional braces. This results in smaller stiffness of the structures retrofitted by BRBs. However the ductility of the structure retrofitted with BRBs increases because the sudden drop of strength in buckled braces is prevented.

\subsection{Time History Analysis Results}

The earthquake records LA 41 to LA 60 developed for the SAC steel Phase II Program [16] were used for seismic performance evaluation of the model structures. The characteristics of the earthquake records, such as magnitude and peak ground acceleration, were summarized in Table 6. Fig. 13 depicts the response spectra of the 20 earthquake records after being scaled to fit the design spectrum of the Korea Building Code [17] and the design spectrum of KBC 2005. 


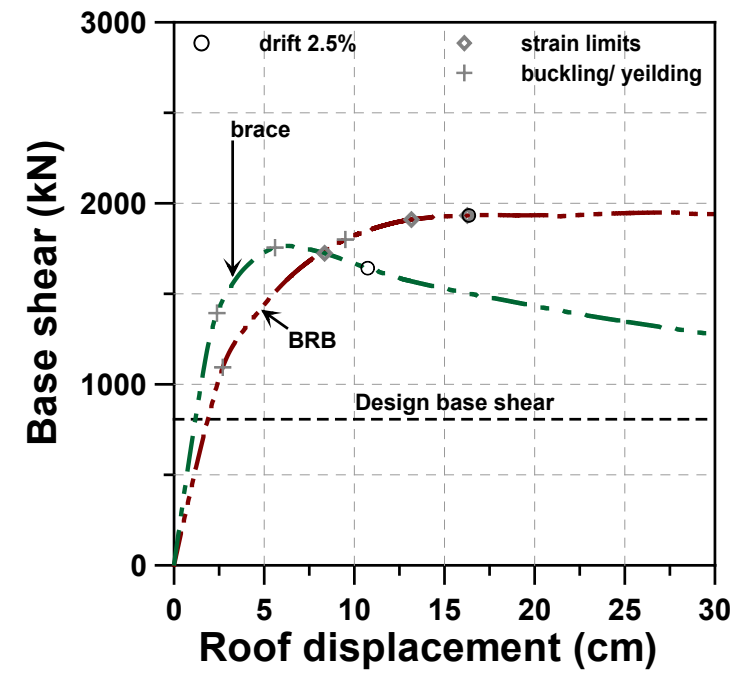

Figure 12. Pushover curves of 3-story structure retrofitted by steel braces and BRBs

Table 7 summarizes the fundamental natural periods and nonlinear dynamic time-history analysis results of the model structures with and without seismic retrofit. The mean and/or median values of the analysis results for the 20 earthquake records were presented in the table. It can be observed that after the retrofit the responses such as inter-story drift and bending deformation of columns and effective beams decreased. The reduction in natural periods is most significant when the structures are retrofitted with steel braces. This results in larger stiffness of the structures retrofitted by braces. Fig. 14 presents the mean response spectra of the 20 earthquake records and the design spectrum with the fundamental periods of the model structures with and without retrofit indicated along the horizontal axis. It can be noticed that after the seismic retrofit the natural periods decreased and the acceleration response generally increased.

Table 6. Characteristics of the LA $41 \sim$ LA60 earthquakes used for time-history analyses

\begin{tabular}{|c||c|c|c||c|c|}
\hline & M & PGA(g) & & M & PGA(g) \\
\hline \hline LA41 & 5.7 & 0.59 & LA51 & 6.1 & 0.78 \\
\hline LA42 & 5.7 & 0.33 & LA52 & 6.1 & 0.63 \\
\hline LA43 & 6.5 & 0.14 & LA53 & 6.1 & 0.69 \\
\hline LA44 & 6.5 & 0.11 & LA54 & 6.1 & 0.79 \\
\hline LA45 & 7.7 & 0.14 & LA55 & 6.0 & 0.52 \\
\hline LA46 & 7.7 & 0.16 & LA56 & 6.0 & 0.38 \\
\hline LA47 & 7.3 & 0.34 & LA57 & 6.5 & 0.25 \\
\hline LA48 & 7.3 & 0.31 & LA58 & 6.5 & 0.23 \\
\hline LA49 & 6.2 & 0.32 & LA59 & 6.0 & 0.77 \\
\hline LA50 & 6.2 & 0.55 & LA60 & 6.0 & 0.48 \\
\hline
\end{tabular}

Table 7. Dynamic analysis results of the model structures subjected to LA41 $\sim 60$ earthquakes

(a) 3-story structure

\begin{tabular}{|c|c|c|c|c|c|}
\hline & No reinforcement & Column jacketing & $\begin{array}{c}\text { Col. jacketing+ } \\
\text { slab reinforcement }\end{array}$ & Brace & Brace+slab reinforcement \\
\hline \hline Natural period & 0.711 & 0.576 & 0.555 & 0.354 & 0.350 \\
\hline $\begin{array}{c}\text { Max. inter-story drift } \\
\text { (median/mean) }\end{array}$ & $1.33 / 1.78$ & $1.19 / 1.34$ & $1.06 / 1.21$ & $0.51 / 0.78$ & $0.53 / 0.83$ \\
\hline $\begin{array}{c}\text { Column strain } \\
\text { (median/mean) }\end{array}$ & $0.004963 /$ & $0.001528 /$ & $0.001486 /$ & $0.001534 /$ & $0.001794 /$ \\
& 0.006319 & 0.002335 & 0.002497 & 0.002939 & 0.00314 \\
\hline $\begin{array}{c}\text { Max. strain of effective } \\
\text { beam } \\
\text { (median/mean) }\end{array}$ & $0.001803 /$ & $0.00217 /$ & $0.001161 /$ & $0.000758 /$ & $0.000569 /$ \\
0.002880 & 0.004019 & 0.002883 & 0.001236 & 0.000694 \\
\hline
\end{tabular}

(b) 6-story structure

\begin{tabular}{|c|c|c|c|c|c|}
\hline & No reinforcement & Column jacketing & $\begin{array}{c}\text { Col. jacketing+ } \\
\text { slab reinforcement }\end{array}$ & Brace & Brace+slab reinforcement \\
\hline \hline Natural period & 0.711 & 0.576 & 0.555 & 0.354 & 0.350 \\
\hline $\begin{array}{c}\text { Max. inter-story drift } \\
\text { (median/mean) }\end{array}$ & $1.33 / 1.78$ & $1.19 / 1.34$ & $1.06 / 1.21$ & $0.51 / 0.78$ & $0.53 / 0.83$ \\
\hline $\begin{array}{c}\text { Column strain } \\
\text { (median/mean) }\end{array}$ & $0.004963 /$ & $0.001528 /$ & $0.001486 /$ & $0.001534 / 0.002939$ & $0.001794 /$ \\
\hline $\begin{array}{c}\text { Max. strain of effective beam } \\
\text { (median/mean) }\end{array}$ & 0.006319 & 0.002335 & 0.002497 & 0.00314 \\
\hline
\end{tabular}




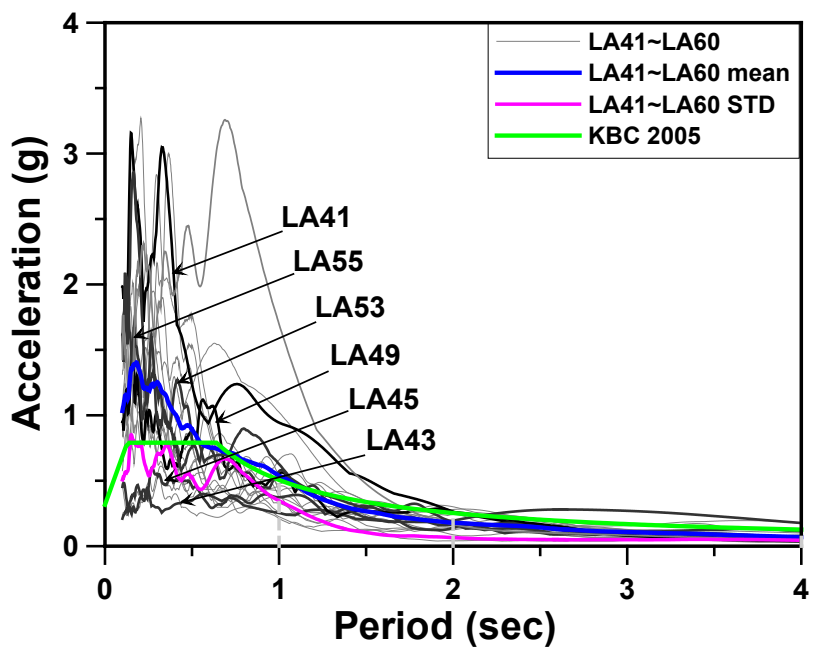

Figure 13. Response spectra of the LA41 to LA60 earthquakes

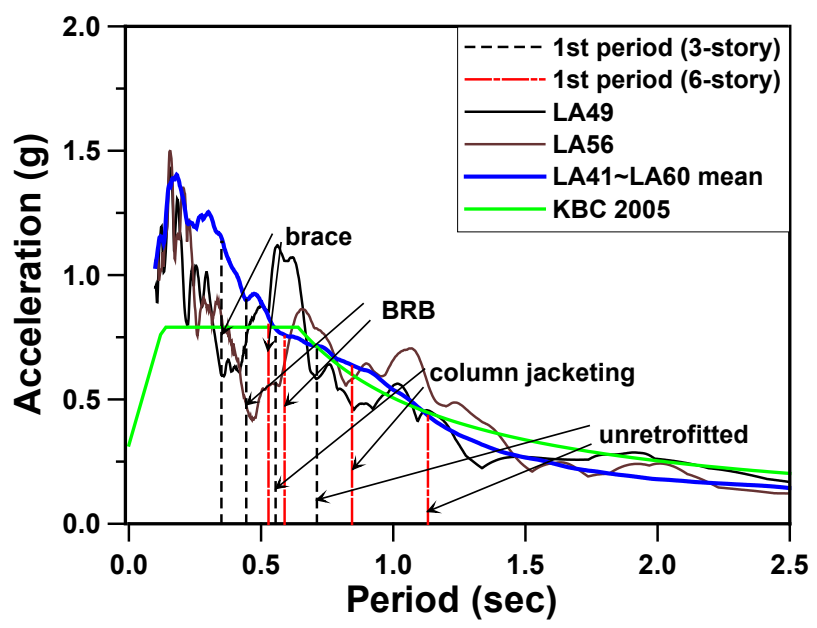

Figure 14. Response spectra of the model structures with and without retrofit

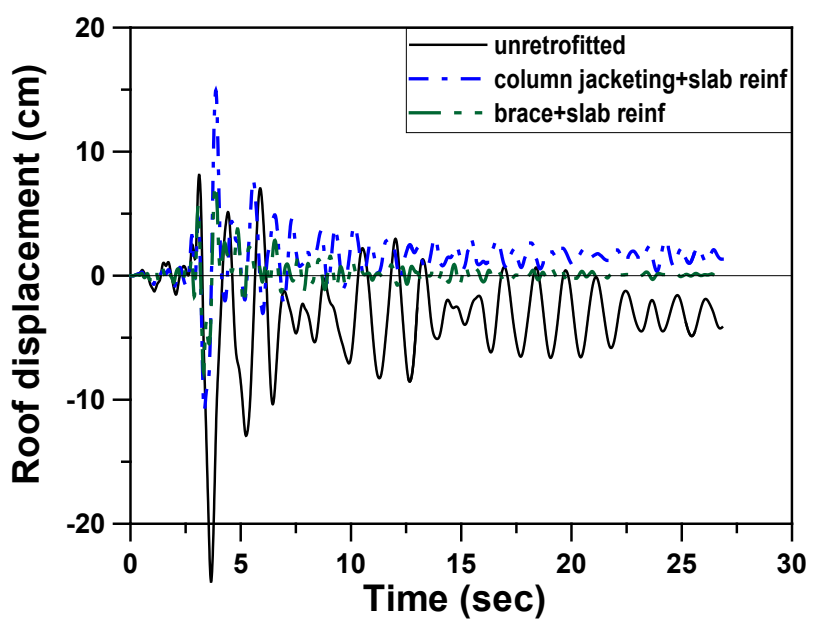

(a) 3-story (LA-41)

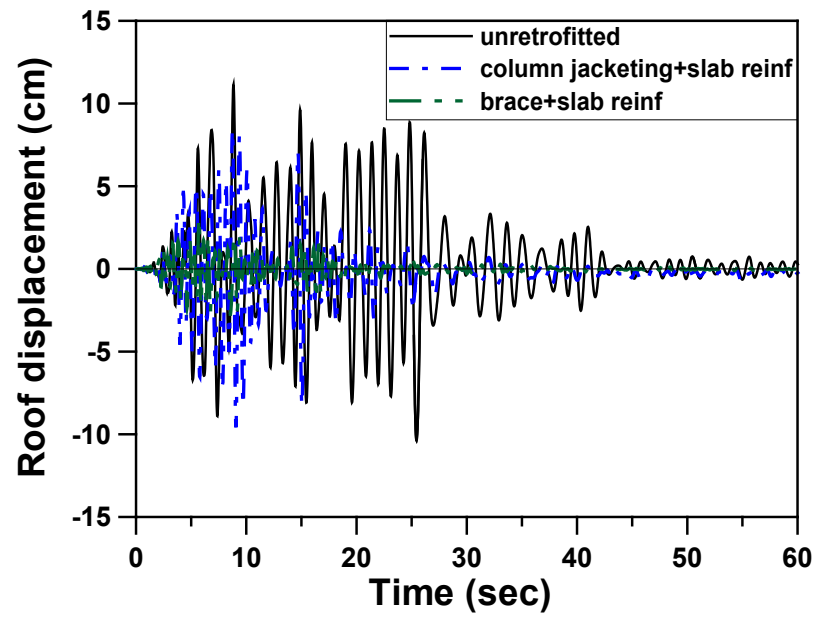

(b) 3-story (LA-49)

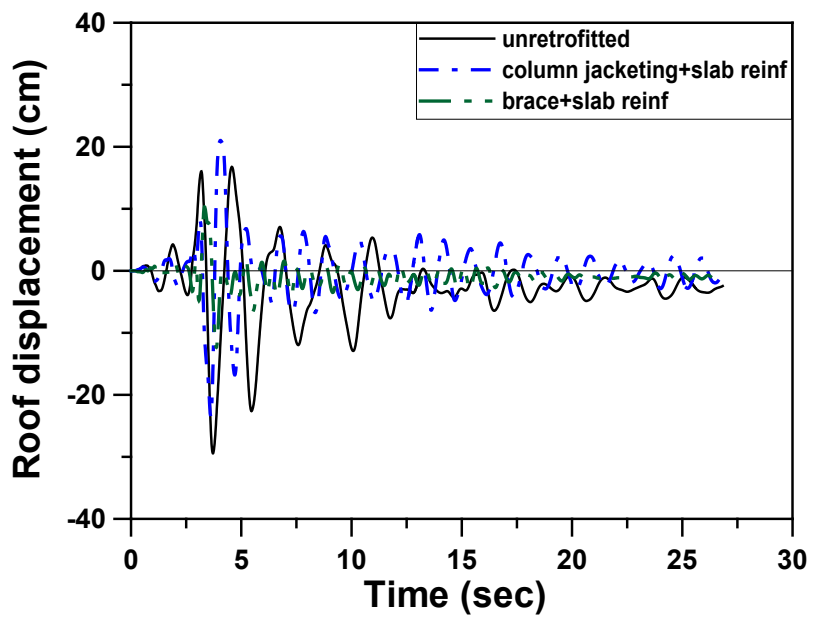

(c) 6-story (LA-41)

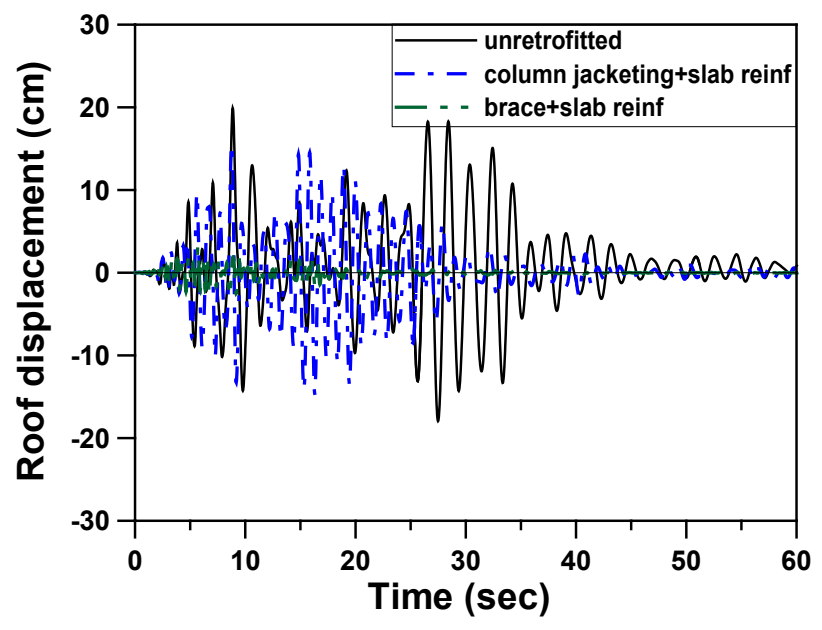

(d) 6-story (LA-49)

Figure 15. Roof displacement time-histories of model structures with and without retrofit

Fig. 15 shows the time histories of the roof displacement of model structures subjected to the LA 41 and LA 49 ground motions. It was observed that in the unretrofitted structures many plastic hinges formed in structural 
members in lower stories, whereas in the retrofitted structures few plastic hinges were observed. Especially in the 3-story unretrofitted structure large permanent displacement and punching shear failure occurred, which disappeared in the structure retrofitted by steel braces.

Fig. 16 shows the inter-story drifts of model structures, where it can be observed that in unretrofited structures large inter-story drift occurs in lower stories, whereas in retrofitted structures the inter-story drifts are relatively uniform. This implies that in unretrofitted structures plastic hinges form mainly in lower stories, whereas in retrofitted structures plastic hinges are uniformly distributed along the height.

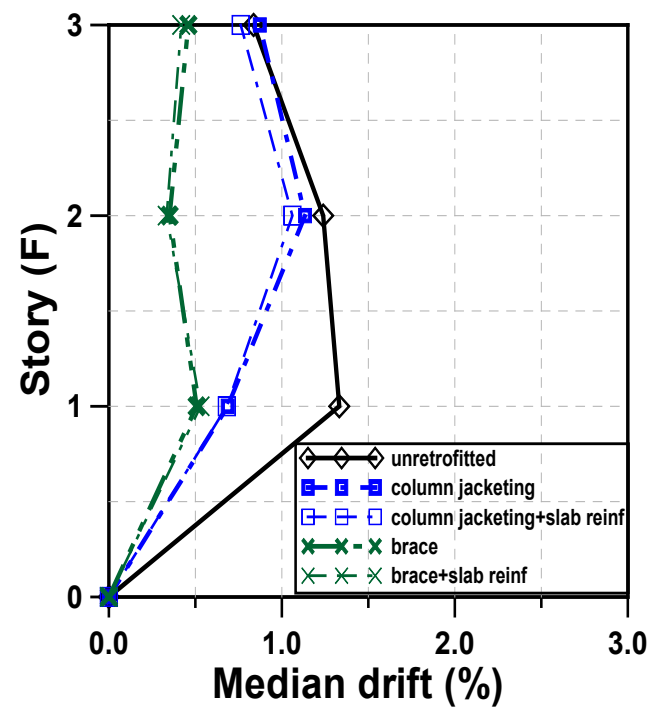

(a) 3-story

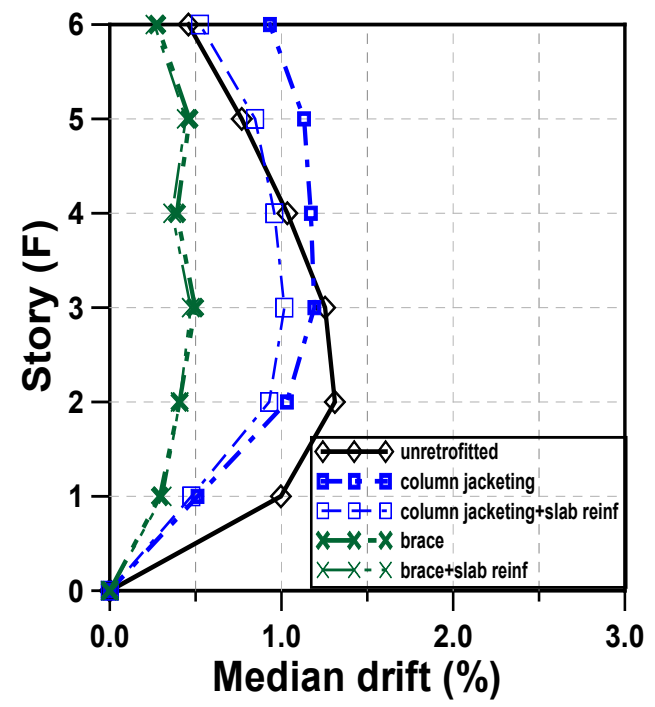

(b) 6-story

Figure 16. Median inter-story drift of model structures obtained from dynamic time-history analysis

Fig. 17 compares the hysteresis curves of base shear-roof displacement relationship of model structures retrofitted by steel braces and BRBs subjected to LA 49 earthquake. It can be observed that the 3-story structure behaved almost elastically after the retrofit, and the area enclosed by the hysteresis curve is larger in the 6-story structure retrofitted by BRBs. This implies that more energy is dissipated in the structure retrofitted by BRBs.

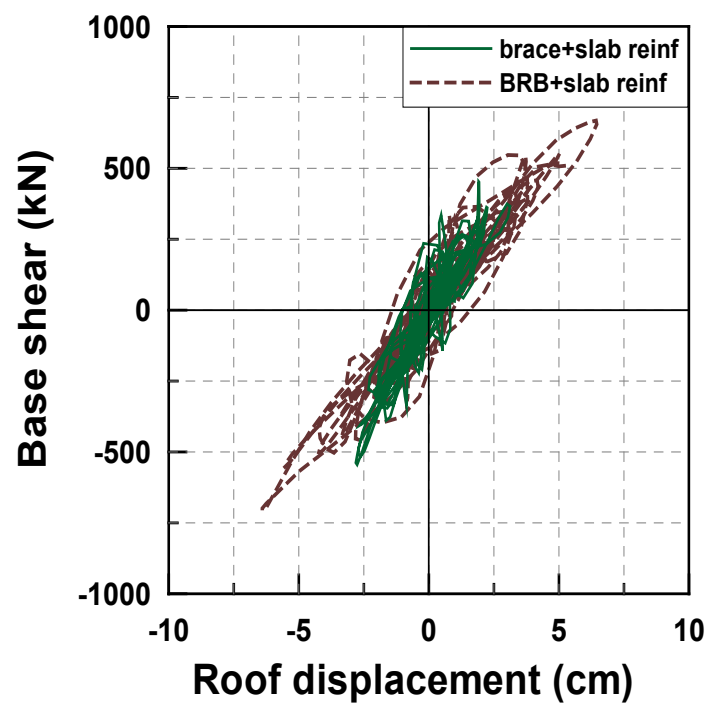

(a) 3-story

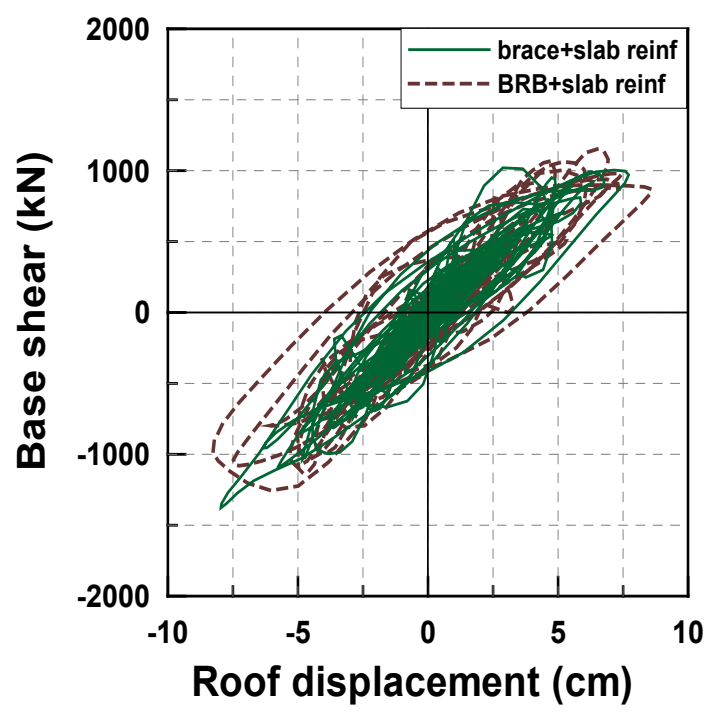

(b) 6-story

Figure 17. Base shear-roof displacement relationships of model structures retrofited by braces (LA49 earthquake)

\subsection{Incremental dynamic analysis results}

In this section the seismic performance of the 3-story model structure was evaluated through incremental dynamic analyses [18] using the six ground motion records (LA41, LA43, LA45, LA49, LA53, and LA55). A series of nonlinear dynamic analyses were carried out by gradually increasing the amplitude of the records and the change in the dynamic response characteristics of the structure was monitored. Fig. 18 presents the spectral acceleration response $v s$. roof displacement curves of the structure 
before and after the retrofit, where it can be observed that the unretrofitted structure generally reached collapse mechanism at the response spectrum value of $1.5(\mathrm{~g})$ and that the overall stiffness and strength increased significantly after the seismic retrofit. The increase in strength and stiffness of retrofitted structure varied depending on the retrofit schemes.
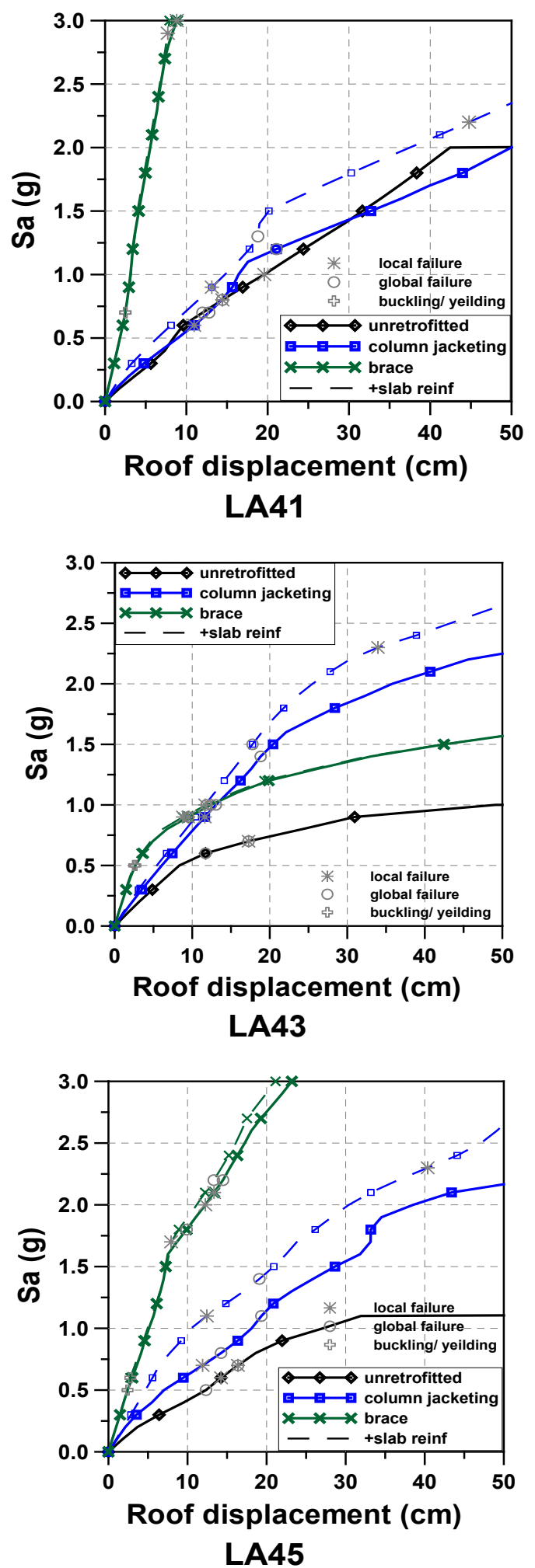

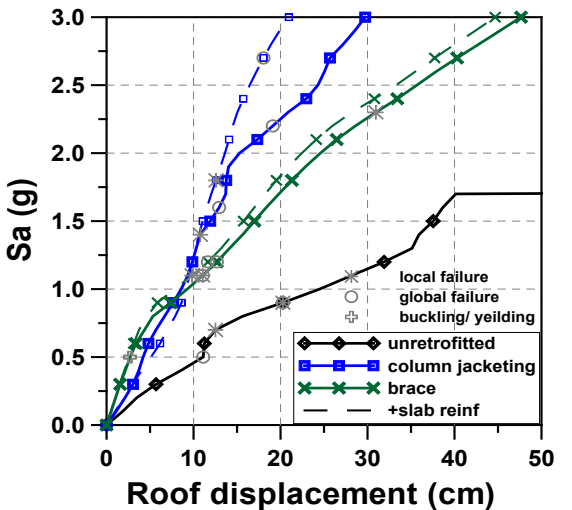

LA49

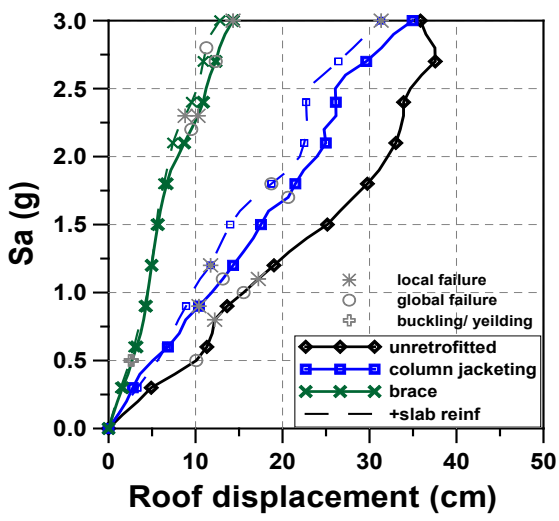

LA53

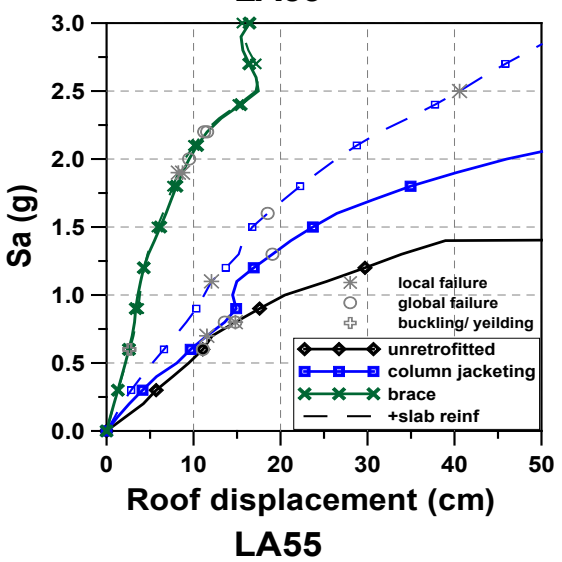

Figure 18. Incremental dynamic analysis results of the 3-story model structure

Fig. 19 compares the base shear-roof displacement relationships obtained by incremental dynamic analysis and static pushover analysis. In the incremental dynamic analysis curve the base shear was obtained at the time step of the maximum roof displacement. All the retrofit schemes included steel plate reinforcement of the column-slab connections to prevent premature punching shear failure. It can be observed that the results generally correspond well with each other in the initial stiffness and the failure points. However the maximum strengths of the unretrofitted structure and the structure with steel braces/BRB predicted by the IDA are slightly smaller than those obtained by pushover analysis. 


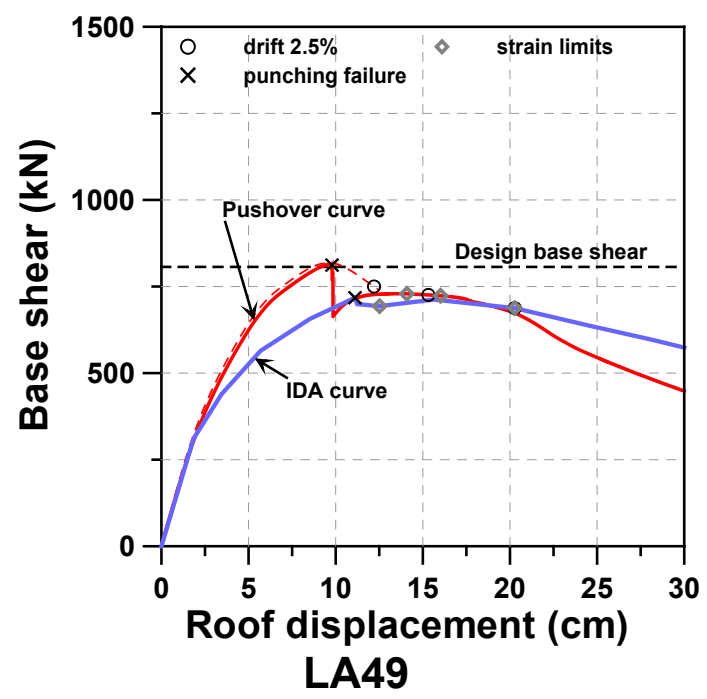

(a) Unretrofitted structure

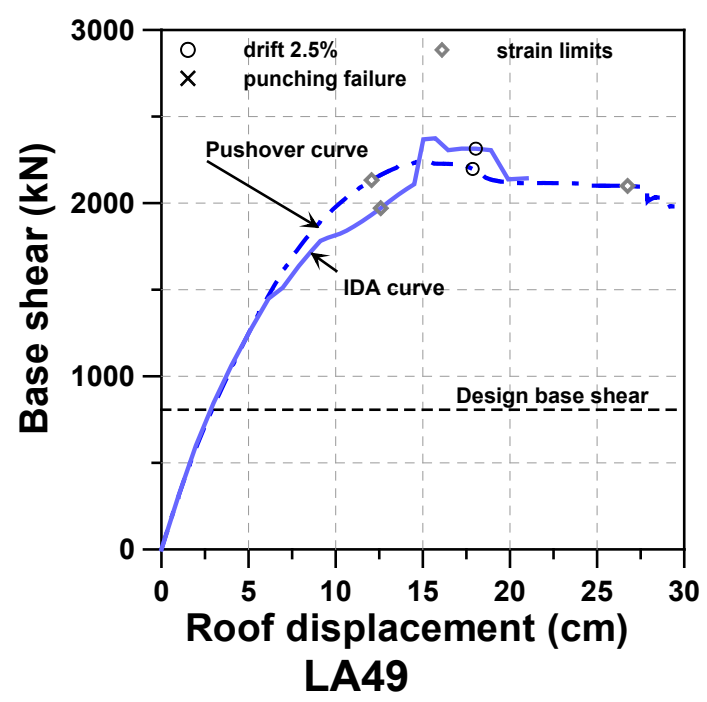

(b) Column jacketing

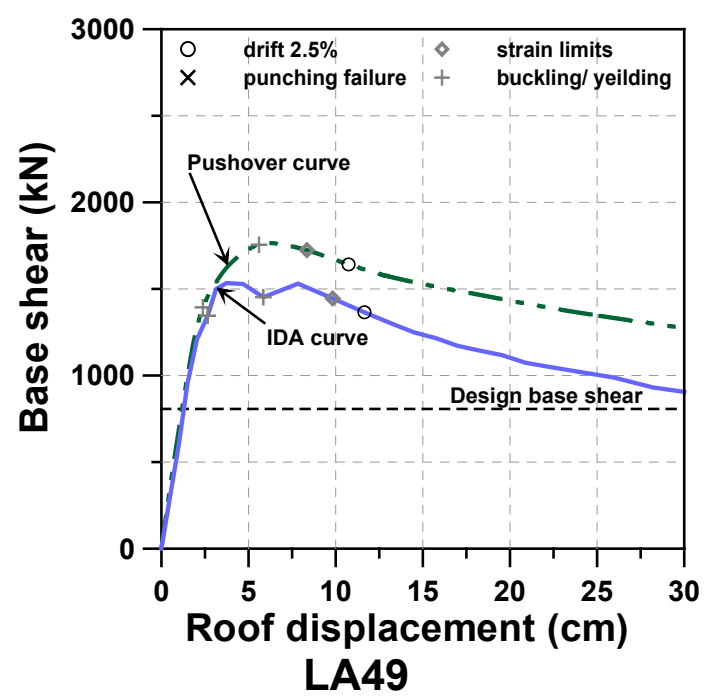

(c) Steel braces

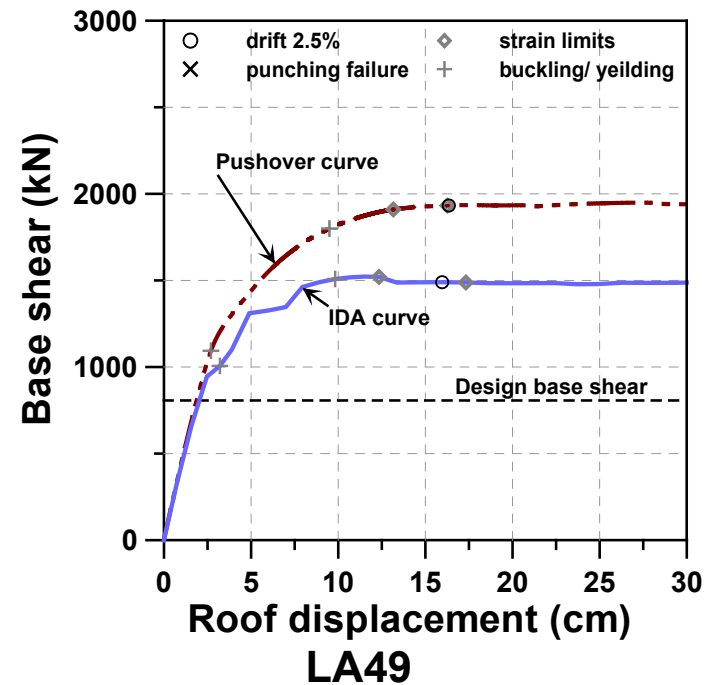

(d) BRBs

Figure 19. Comparison of the pushover and the IDA curves of the 3-story structure

\section{Conclusions}

In this study 3- and 6-story flat plate structures were designed without considering seismic load and were retrofitted with steel plates and braces to meet current design seismic load. The seismic performances of the model structures were evaluated by nonlinear static and dynamic analysis methods to verify the effect of the seismic retrofit.

According to the analysis results the unretrofitted model structures failed by punching shear of column-slab connections. However after the seismic retrofit both the strength and stiffness were significantly enhanced enough to satisfy current seismic design codes. The ductility of the structure was significantly increased when the critical section of a column-slab connection was reinforced by steel plate to prevent punching shear failure. Among the retrofit schemes installation of steel braces were most effective in increasing stiffness as well as strength, and the effectiveness depended on the size of additional steel columns connected to the braces. When buckling-restrained braces were used instead of conventional steel braces, the structures showed more ductile behavior, especially in the 3 -story structure.

\section{Acknowledgements}

This research was supported by a grant funded by the Ministry of Land, Iinfrastructure and Ttransport of Korea through the 'SPEC' research project.

\section{REFERENCES}


[1] Goel, S.C., Masri, A.C. (1996), Seismic Strengthening of an RC Slab-Column Frames with Ductile Steel Bracing, 11th World Conference on Earthquake Engineering, Paper No. 506.

[2] Masri, A. and Goel, S. (1996), Seismic Design and Testing of an RC Slab-Column Frame Strengthened with Steel Bracing, Earthquake Spectra, 12(4), pp. 645-666.

[3] Luo, Y.H. and Durrani, A.J. (1995), Equivalent beam model for flat-slab buildings - partl: interior connections, ACI Structural Journal, 92(1), pp.115 124.

[4] Luo, Y.H. and Durrani, A.J. (1995), Equivalent beam model for flat-slab buildings - partll: exterior connections, ACI Structural Journal, 92(2), pp.250 257.

[5] Martinez, J., Qaisrani, A., Moehle, J. (1994), Post-Tensioned Flat Plate Slab-Column Connections Subjected to Earthquake Loading, 5NCEE, Chicago.

[6] Mazzoni, S., McKenna, F., Scott, M.H., and Fenves, G.L. (2006), Open System for Earthquake Engineering Simulation OpenSees Command Language Manual, Pacific Earthquake Engineering Research Center, Berkeley, California.

[7] Hueste, M.B.D. and Wight, J.K. (1999), Nonlinear punching shear failure model for interior slab-column connection, Journal of Structural Engineering, 125(9), pp.997 1008.

[8] Mander, J.B., Priestley, M.J.N., and Park, R.(1988), Theoretical stress-strain model for confined concrete, Journal of Structural Engineering, 113(8), pp.1804 1826.

[9] Vanderbilt, M.D. and Corley, W.G. (1983), Frame analysis for concrete buildings, Concrete International : Design \& Construction, 5(12), pp. $33 \sim 43$
[10] ACI Committe 318(2005), Building code requirements for structural concrete and commentary, American Concrete Institude, Detroit

[11] Choi, J., Song, J., Yoon, J, and Lee, S., (2002), Analytical model for RC flat plate structures subjected to lateral load, J. of Architectural Institute of Korea, 18(3), pp. $37 \sim 46$

[12] Park, Y., Han, S., and Oh, S. (2006), Stiffness reduction factor for analysis of flat plate slabs, J. of Architectural Institute of Korea, 22(11), pp.105 114

[13] Elwood, K.J. and Moehle, J.P. (2008), Dynamic collapse analysis for a reinforced concrete frame sustaining shear and axial failures, Earthquake Engineering and Structural Dynamics, online publish

[14] IBC (2009), International Building Code, International Code Council, Inc., Falls Church, VA

[15] Susantha, K.A.S., Ge, H., and Usami, T. (2001), Uniaxial stress-strain relationship of concrete confined by various shaped steel tubes, Engineering Structures, 23(10), pp.1331 1347 .

[16] Somerville, P. Smith N., Puntamurthual, S. and Sun, J. (1997), Development of ground motion time histories for phase 2 of the FEMA/SAC steel project, Background document, Report No. SAC/BD-97/04

[17] Korea Building Code (2009), Architectural Institute of Korea

[18] Vamvatsikos, D. and Cornell, C.A. (2002), Incremental dynamic analysis, Earthquake Engineering and Structural Dynamics, 31(3), pp. $491 \sim 514$ 